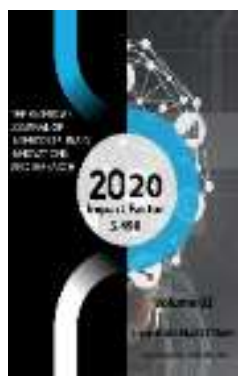

Journal Website: http://usajournalshub.c om/index,php/tajiir

Copyright: Original content from this work may be used under the terms of the creative commons attributes 4.0 licence.

\section{The Issue Of The Central Asian Northern Pilgrimage Route In The Russian-Bukhara Diplomatic Relations In The XVIII Century (On The Example Of The Activities Of Ambassador Ernazar Maqsud Oglu)}

\author{
Tanieva Guldona Mamanovna \\ Senior Researcher Of The Institute Of History Of The Academy Of Science Of The Republic Of \\ Uzbekistan
}

\title{
ABSTRACT
}

In the Middle Ages, Central Asian pilgrims traveled to Mecca in three directions: the North direction through the Russian Empire, the central direction- through the territory of Persia, and the south direction - along roads through India and the Arabian Sea. Therefore, the question of the directions of the Hajj was reflected in the diplomatic correspondence of the Central Asian khanates with Persia, India, the Russian and Ottoman empires too. Depending on the political, economic and ideological interests of these states, sometimes pilgrims were given permits to be sent to Mecca through their territories, and sometimes not. The degree of intensity of pilgrimage movements, in most cases, depended on the activities of interstate ambassadors. On the issue of eliminating various prohibitions and obstacles in the movements of pilgrimage roads, the Central Asian ambassadors were active and historical documents reveal these data to us.

In this period the Central Asian ambassadors, who were sent to the reception of the governors those neighbor states on other issues, in most cases negotiated precisely on the direction of the Hajj of the Central Asian pilgrims also. One of such far-sighted ambassadors was a rich merchant from Bukhara, who lived in the XVIII c. Ernazar Maksud ogli officially sent several times by the Central Asian rulers to the Russian Empire. In this article analyzes the question of how the problems of the Hajj road were solved at the international diplomatic level by the example of the activities this ambassador. The history of negotiations between Ernazar and the Russian emperors on matters of the northern direction of the Hajj road and their results illuminated on base documents on this issue, which stored in the fund of the Archive of Foreign Policy of the Russian Empire (AFPRE). The scientific conclusions of this article serve for an extensive study of the issues of diplomatic and economic relations between the Central Asian khanates and the Russian Empire in the XVIII century, revealing the history of the embassy relations of the khanates and the history of the pilgrimage of the Hajj of the Central Asian people and the features of the directions of roads from Central Asia to Mecca. 


\section{KEYWORDS}

Central Asia, Central Asian khanates, hajj, Mecca, pilgrim, Russian empire, ambassador, Muslims, diplomacy, Ernazar Maksud ogli, archive, the 18th century, hajj roads, Astrakhan, Islam.

\section{INTRODUCTION}

In the Middle Ages, Central Asian Muslims made the pilgrimage to Mecca in three directions: through the North-Russian Empire, through Central-Iran, and through South-India and the Arabian Sea. Visitors are sometimes allowed and sometimes banned by various states, depending on the political situation, to cross these routes. The quality of the pilgrimage was largely dependent on the services of international ambassadors between states. Central Asian ambassadors were active in overcoming various prohibitions and barriers to pilgrimage, and information about this has been preserved in historical documents.

It is known that in the XV-XVI centuries the main road connecting Russia and Central Asia passed through the city of Astrakhan, and Central Asian pilgrims traveling to Mecca in the northern direction often followed this route. When the city of Orenburg was built in 1743, the road connecting the cities of Central Asia and Russia was considerably shortened. On April 25, 1750, a man named Sherbek was sent by the khan of Khiva Goibkhon Botir oglu (1746-1756) was sent as an ambassador to the first governor of the Orenburg province I.I.Neplyuev (1744-1757). He was not only the first of the ambassadors from Khiva to Orenburg, but also the first of the ambassadors who raised the issue of the pilgrimage through this city. Ambassador Sherbek asks permission for Khiva pilgrims going to Mecca to pass through Astrakhan [6: 219]. Although the ambassador was not allowed to go to St. Petersburg to the Foreign Affairs Board to address the issue, he managed to get permission from the governor to allow the Khiva pilgrims to travel through Astrakhan.

There are many documents on this subject in various funds of the Foreign Policy Archive of the Russian Empire. For example, documents from the archives of Snosheniya Rossii s Khiva (Russia's Relations with Khiva) show that in July 1751, you can read the information about the permission request of Khiva's ambassador Nurillaboy took the khan's official letter to St. Petersburg, so that Khivaites could travel to the Ottoman Empire (1299-1922) through Russian cities. On September 10, 1751, the Russian Emperor Elizabeth Petrovna (17091761; reigned 1741-1761) sent a letter to the governors-general of Astrakhan and Orenburg requesting that Khiva be allowed to pass through Russian cities for pilgrimage.

Ambassadors were also sent on behalf of Bukhara khan Abulgazikhan (d. 1795-96; reigned 1758-1785) on the issue of the Russian pilgrimage, one of whom was Mulla Ernazar Maqsud oglu, a great merchant from Bukhara who lived in the second half of the XVIII century. According to historical data, the son of Mulla Ernazar Maqsud many times traveled 
with his caravans to the cities of Russia and India for trade. This man, who had traveled to many countries and had extensive experience, was also received by the rulers of neighboring states as the official ambassadors of several rulers, in addition to his business dealings. In particular, the fact that he was received by several Russian emperors confirms the information in the archives. In particular, in 1762 he was appointed as an official ambassador for trade in the presence of the Kazakh khan Nuralikhan (1710-1790; reign 1748-1786) to Peter III (1728-1762; reign 17611762), on behalf of the Bukhara khan Abulgazi Muhammad Bahodirkhan for the first time in 1774-1775, and for the second time in 17791780 in the palace of Catherine II (1729-1796; reign 1762-1796). According to a document registered in the Foreign Policy Archive of the Russian Empire on June 6, 1762, he had been involved in trade with Russia for many years since 1745 and on behalf of the emperors, in the words of the ambassador, "without saving his life and money", visited Bukhara, India, Khorasan and other dangerous places and cited their orders. For 35 years, until the end of his life, he actively cooperated in trade with the Russian emperors, especially Elizabeth (17411761) and Catherine II [2: I. 4-5].

His work on the issue of pilgrimage is reflected in some documents kept in the Foreign Policy Archive of the Russian Empire. In the volumes of the official documents of the embassy, it is mentioned that Mulla Ernazar Maqsud oglu twice visited the imperial palace through the sentences "The first embassy of Ernazar Maqsud oglu", "The second embassy of Ernazar Maqsud oglu" [2: I. 1; 3: I. 1].
It is noteworthy that before these two embassies, Mulla Ernazar Maqsud oglu came to St. Petersburg in 1762 as an ambassador to Peter III on behalf of the Kazakh khan Nuralikhan, that is, in the name of his former emperor Elizabeth, to exchange livestock between the Emba and Yayik rivers had brought the letter he had written. At the same time, Ernazar Maqsud oglu handed over a letter to Peter III on behalf of all Muslims of Bukhara on the issue of Hajj. The ambassador congratulates the emperor on his accession to the throne and states that he was in India, Bukhara, Khiva, Khorasan and other dangerous places on the instructions of the former emperor Elizabeth. The purpose of the letter was to "convey the great request of the people of Bukhara" to obtain permission from the emperor to move freely to and from Astrakhan for a visit to Mecca. Both the Orenburg and Mangyshlak roads, which were prosperous, were asked to be given official permits with state seals guaranteeing the safe passage of pilgrims [2: I. 6].

Interestingly, the archive "Snosheniya Rossii s Bukhara" ("Russia's relations with Bukhara") also contains a reference to the content and purpose of the letter of Ernazar Maqsud oglu, sent to the emperor by the government chancellery in St. Petersburg at the request of Peter III. It states that Ernazar Maqsud's son asked the emperor for permission for the Bukhara people to pass through Russian cities for a trip to Mecca. It was stated that the Khiva residents had asked for permission to pass through Astrakhan, but this request was also denied. The reason for this behavior of the Russian government is that the Khiva khanate 
was dependent on the Safavid state (15011785) at that time [2: I.11]. After the conquest of Khorezm in 1740, the Safavid ruler Nadirshah Afshar (1688-1747; reigned 1736-1747) appointed a number of his subjects as khans. At the time of the ambassador's arrival from Khiva to Astrakhan, Goibkhan (1745-1756) was sitting on the throne in the khanate with the consent of Nodirshah. The Russian government did not want to establish embassy relations with the Safavids, a semi-dependent state (Khiva). According to the document, at that time, in 1751, the governor of Astrakhan, a secret adviser I.Brilkin, was openly told to "excuse" the Khiva people from the capital to go on pilgrimage through this route and not to allow them. Also, the attempts of spies sent by the Ottoman Turks to gather secret information in Russian cities under the guise of Central Asian pilgrims were recognized as the main reason for this ban [2: I.11].

According to a collection of documents on the Second Embassy of Ernazar Maqsud's son, he and his son Muhammad Sharif arrived in St. Petersburg in 1779, this time to two countries at once - first to Russia and then through him to the Ottoman Sultan Abdulhamid I (17251789; reign 1773-1789) was sent to him as an ambassador. The mission of the embassy is to establish trade relations between the two countries, as well as to resolve the issue of the transition to the Ottoman territory via Russia for a visit to Mecca [8: 178-179]. In June 1780, he asked the emperor for permission for the Bukhara pilgrims to pass through Russian territory into the territory of the Ottoman state without any obstacles. This request of the ambassador was answered positively and all conditions were created for him to leave the capital and go to Istanbul via Kherson, the
Black Sea, and was transferred to the territory of the Ottoman state [ $4: 1.60,73 ; 11: 10]$.

In October-November 1780, Ambassador Ernazar held political and trade talks with the Ottoman Minister of State. Unfortunately, he set out for his personal goal of performing the hajj, and in September 1781, he fell ill on the way to Kunya, Turkey, before reaching Mecca [7: 107].

According to $\mathrm{H}$. Ziyoev, who in his time studied and analyzed historical data on the subject, Bukhara khan Abulgazi Muhammad Bahodirkhan sent a letter to the Russian emperor thanking the ambassador Mulla Ernazar for his worthy observation of the territory of the Ottoman state [9:34].

These documents also contain historical information that his brother Avazberdi Maqsud oglu, who remained in Moscow on June 18, 1782, a year after the death of Mulla Ernazar, also asked the Russian ruler for permission to perform the pilgrimage. Interestingly, he was not actually an official ambassador, but joined his brother from Bukhara, and continued to serve as his brother's pilgrimage mission, despite the fact that the embassy had already left Russia. For example, according to the collection of documents of Avazberdi Maqsud oglu of the State Archives of Foreign Policy of the Russian Empire, he appealed to the Board of Foreign Affairs of Russia to ensure the free movement of Bukhara residents through Moscow to visit Mecca. He also attached the following list of 21 Bukhara residents of Moscow who went on pilgrimage with him:

1.Avazberdi Maqsud oglu,

2.Mirsalim Mirabdul oglu, 
3. Rajab Ashirbaqi oglu,

4.Uzbekkhoja Muhammadkhoja oglu,

5.Abdurahmonbek Oltinbek oglu,

6.Muhammadsalim Ashurmuhammad oglu,

7.Allahqul Khudoyqul oglu,

8. Faizullah Avazberdi oglu,

9.Qurban Allahqul oglu oglu,

10. Shoin Zamon oglu,

11.Abduhaliq Sheikhdo'st oglu oglu,

12. Mominjon Mirsolih oglu,

13.Nekqadam Abdul oglu,

14.Boboshih Rahimshih oglu (Boboshaykh, Rahimshaykh - G.T.)

15.Asan (Hasan - G.T.) Sodiq oglu,

16.Abdullahhoja Muhammadhoja oglu,

17.Kurban Mumin oglu,

18.Belil Ashur oglu,

19. Khoja Boqi oglu,

20.Qurbonboy Rahim oglu,

21. Vafoshah Arabshah oglu [3: I. 1, 2].

Whether he came to Russia as part of an embassy mission led by Mulla Ernazar Maqsud oglu, or because he is a relative of the esteemed ambassador, or for some other reason unknown to us, his request was granted. In fact, with his appeal, orders were sent to the Orenburg, Kazan, Azov, Kiev, Novosibirsk provinces and to the heads of border posts to ensure the smooth passage of
Central Asian pilgrims [3: I. 8, 9, 10]. From this it can be seen that Avazberdi Maqsud oglu was highly respected by the government.

According to archival documents, the order, issued on the basis of the appeal of Avazberdi Maqsud oglu, remained in force for four years. Among the documents in the archives from September 3 to October 21, 1785 are correspondence between the Governor of Siberia, Ufa, Lieutenant-General Baron Osip Andreevich Igelstrom (1737-1823) and the Board of Foreign Affairs. One of them states that Nematullo Nazirmuhammad oglu, who came to Orenburg from Bukhara, asked the governor for permission to visit Mecca through Russian territory. The document states that his name was not included in the list provided by Avazberdi Maqsud oglu four years ago, however, that he was allowed to travel to Mecca through Russian territory [3: I. 31, 34].

In fact, according to the archival documents analyzed above, although Mulla Ernazar Maqsud's son died before reaching Mecca, the fifth obligatory pilgrimage, he carried out the mission of the embassy mission for Central Asian Muslims through the cities of Russia indicates that it has fully performed the task of obtaining permission to increase. His business acumen, knowledge, and diplomatic potential enabled Central Asian pilgrims to take advantage of this opportunity for a long time, even after his death.

The analysis of the above-mentioned archival documents allows us to draw the following conclusions, firstly, that the rulers of Central Asia often sent ambassadors to neighboring countries, in particular, Russian cities, to visit Mecca. Second, no matter how skilled diplomats these ambassadors may be, or 
whether they insist that they be allowed to do so, they will not give a positive result if these requests run counter to the interests of the state. Third, such requests from ambassadors from Central Asia between 1751 and 1762 were rejected. The actions of the ambassador from Bukhara, Mulla Ernazar Maqsud oglu, can be considered as the first embassy in this elevenyear period.

The study of archival documents on the activities of Ernazar and Avazberdi Maqsud oglu in this area allows to further study the history of the embassies of Central Asian countries in the XVIII century, diplomatic and economic relations between the Central Asian khanates and Russia.

\section{REFERENCES}

1. Archive of Foreign Policy of the Russian Empire (AVPRI), f-125, Snosheniya Rossii s Khivoy, opis-1, d-3.

2. Archive of Foreign Policy of the Russian Empire (AVPRI). F-109/1, Snosheniya Rossii s Bukhara, opis-1, d-2.

3. Archive of Foreign Policy of the Russian Empire (AVPRI) F-109, Snoshenie Rossii s Bukhara, opis- 2, d-11.

4. Archive of Foreign Policy of the Russian Empire (AVPRI). F-109, Snoshenie Rossii s Bukhara, opis- 2, d-3.

5. Baykova N.B. Rol Sredney Azii v russkoindeyskix torgovyx svyazyax. Tashkent. 1964.

6. Veselovskiy P. Essays on historical and geographical information about the Khivinsk khanate. Ot drevneyshix vremen do nastoyashchago. St. Petersburg, 1877.

7. Vasilev A.D. Znamya i mech ot padishaxa. Politicheskie i kulturnye kontakty xanstv Tsentralnoy Azii i Osmanskoy imperii (seredina XVI - nachalo XX vv.). Moscow. 2014.

8. Gulomov X. Diplomatic relations of the Central Asian states with Russia in the XVIII - first half of the XIX century. Tashkent, 2005.

9. Ziyaev H. Central Asia and the Urals in the XVIII century. Tashkent, 1962.

10. Mixaleva. G.A. Torgovye and posolskie svyazi Rossii so sredneaziatkimi xanstvami cherez Orenburg. Tashkent. 1982.

11. Yakovlev. (The author's initials are not given in the journal) Mulla Irnazar Maksyutov, messenger Bukharskiy // Sibirskiy Vestnik, Ch-1. St. Petersburg, 1824. p. 7-10.

12. Djuraeva, S. (2020). Classification Of Pilgrimages In Sherobod Oasis. The American Journal of Interdisciplinary Innovations and Research, 2(11), 17-20.

13. Djuraeva, S. (2020). Shrines Of The Karshi Oasis. The American Journal of Applied sciences, 2(11), 12-15.

14. Khamidova, M. (2017). Studying of Uzbekistan's architectural monuments at the end of XIX-early XX centuries (on the basis of local archive sources). European Journal of Humanities and Social Sciences, (2), 14-16. 